\title{
Is Material Management Required In Management Silver Craft SMEs? (Case Study in Gianyar Regency of Bali Province. Indonesia)
}

\author{
Putu Yudy Wijaya, I Ketut Rahyuda, Ni Nyoman Kerti Yasa, and I Putu Gde Sukaatmadja
}

\begin{abstract}
The craft industry is growing rapidly in Bali as a support for the tourism sector, moreover Bali is a world tourist destination. One of them is silver craft, which has now developed as a fashion value product. To create a competitive product, which has quality, quality and uniqueness, of course management material (in this case silver as raw material) needs to be considered. The purpose of this study is to analyze the influence of innovation and competitive advantage on business performance, as well as the role of material management on the influence of competitive advantage on the business performance of silver craft SMEs in the Province of Bali. The population in the study was silver craft SMEs in Gianyar Regency, which is the center of the silver industry in Indonesia. The sample size is determined by the formula Isaac and Michael, so that a sample of $\mathbf{1 4 6}$ respondents was obtained. Data was collected through questionnaires and independent interviews. Furthermore, the data were analyzed using the SEM-PLS approach. The results of data analysis show that competitive advantage has a positive and significant effect on business performance, while material management directly or as a moderator turns out to have no significant effect on business performance. It is recommended that silver craftsmen do material management in a simple but careful manner, and focus more on forming product competitiveness.
\end{abstract}

Index Terms-business performance; competitive advantage; material management; silver craft SMEs.

\section{INTRODUCTION}

SMEs have an important role in the Indonesian economy, and are able to survive when the global crisis. One sector supported by SMEs is the tourism sector. The Province of Bali is one of the world's tourist destinations which is also a barometer of the progress of Indonesian tourism. The type of SMEs that plays a role in supporting tourism in Bali is craft SMEs, one of which is jewelry craft. Gem/jewelry in

Putu Yudy Wijaya is a Doctoral Candidate in the Doctoral Program in Management Sciences, Faculty of Economics and Business, Udayana University and lecturer at the Faculty of Economics, Indonesian Hindu University, Denpasar, Indonesia. (e-mail: yudywijaya333@gmail.com).

I Ketut Rahyuda is a professor at the Faculty of Economics and Business, Udayana University, Denpasar, Indonesia. (e-mail: gaerahku@yahoo.co.id).

$\mathrm{Ni}$ Nyoman Kerti Yasa is a professor at the Faculty of Economics and Business, Udayana University, Denpasar, Indonesia. (e-mail: manraikerti@yahoo.co.id).

I Putu Gde Sukaatmadja is a lecturer at the Faculty of Economics and Business, Udayana University, Denpasar, Indonesia. (e-mail: sukaatmadja@yahoo.co.id).
Bali Province mostly comes from the silver craft industry. Therefore, the decline in the export value of gem/jewelry certainly has an impact on the development of the silver craft center in Bali Province. One area in Bali Province which is the center of the silver craft industry is Gianyar Regency.

Preliminary observations show that the condition of the silver industry in Gianyar Regency is in a stagnant condition and even tends to decline. This is evidenced by the existence of dozens of art shops that sell and or produce silver crafts, preferring to close their businesses and switch functions to other businesses. Some of the problems faced by silver craft SMEs such as the lack of visitors who come and order silver crafts, the price of silver material which continues to increase and is rare in the market, and international silver prices are relatively cheaper compared to domestic silver prices because they must be subject to VAT tax. This condition is one of the causes of silver craft businesses in Bali having difficulty competing with foreign competitors. All obstacles faced by SMEs if not addressed immediately will certainly have an impact on the competitiveness of companies and affect the business performance of SMEs.

Raw materials or material procurement are important for organizational performance because they are related to costs, make the best use of available resources, and time to settle (Kathawala and Nauo, 2007; Keitany et al., 2014; Bagaka and Moronge, 2017). The percentage of material costs to the total production costs that are relatively high will have an impact on product efficiency. The efficiency of each activity for the production of goods and services relies heavily on the supply of materials, equipment and available resources in the right proportion (Bagaka and Moronge, 2017), and supplies material control systems (Naliaka and Namusonge, 2015). For this reason, material costs need to be reduced, so as to increase liquidity. Effective supervision of the use of materials reacts more quickly to changes in the market and more reliable turnaround times. Both are clearly important criteria for companies that have competitive advantages (Kathawala and Nauo, 2007). The company's performance will be unstable if raw materials are not managed well (Dreyer and Gronhaug, 2004; Bagaka and Moronge, 2017).

The purpose of this study is to analyze whether competitive advantage influences business performance in silver craft SMEs. The role of the material management moderator on the influence of competitive advantage on business performance in silver craft SMEs in Gianyar Regency was the focus of this research. 


\section{LITERATURE REVIEW}

\section{A. Material Management}

Material management from a holistic perspective can be defined as a process of planning, acquiring, storing, distributing, and supervising material into the final product by utilizing efficient resources, facilities, and capital, so as to be able to provide optimal customer service in accordance with organizational goals (Kathawala and Nauo, 2007). Ondiek et al. (2012) states that material management is a concept that combines processes in manufacturing that begin with the process of scheduling, procuring, storing and issuing raw materials.

Material management is a tool to optimize business performance in meeting customer needs, while increasing profitability by minimizing costs and utilizing available resources efficiently (Keitany et al., 2014). Raw material management aims to produce products in a timely manner, in the right place with good quality, so as to provide optimal service to customers at minimum costs. For this reason, effective relationships and material monitoring systems are needed at each stage of the flow. An integrated and systematic approach is needed to control the material flow of each stage of production at the company (Kathawala and Nauo, 2007).

Effective inventory management can create a sustainable competitive advantage and enhance the competitiveness of the company. This condition can be achieved, if the cost of storing material supplies is low and can maintain material inventories in the right amount, place, time of the product needed. High inventory of raw materials will affect the company's financial performance, because it has an impact on cash flow and a decrease in financial efficiency and effectiveness (Naliaka and Namusonge, 2015). Material management can be measured based on two dimensions, namely: (1) inventory control systems, (2) material procurement (Bagaka and Moronge, 2017). Inventory control system is a material arrangement activity that aims to know the actual material to fit the conditions set during planning. Material inventory control systems are measured by indicators: stock planning, stock ordering, stock scheduling / tracking, warehousing and storage, turnaround and realignment (Bagaka and Moronge, 2017). Material procurement is all activities or businesses to add, fulfill material needs in the production process. Material procurement can be measured by indicators: Determining order quantities, agile sourcing, supplier valuation, negotiation, purchase, invoice auditing, quality control, receipts and inspection of goods, clarifying payments (Bagaka and Moronge, 2017). Koumanakos (2008) measures material management using indicators: the period of inventory duration.

Keitany et al. (2014) measure material management based on two dimensions, namely: (1) Inventory control and (2) Lead time. Dreyer and Gronhaug (2004) state that material management is a factor that is uncertain and is flexible. The indicator used to measure it is the composition of the volume of raw material for the product.

This study uses material management variables measured by the dimensions of material procurement systems, inventory control systems, and lead time (Dreyer and
Gronhaug, 2004; Keitany et al., 2014; Bagaka and Moronge, 2017). The dimensions of the material inventory system are reflected by indicators (1) material quality, (2) inventory management. Material control systems are reflected by indicators (1) material distribution, (2) storage, for lead time dimensions measured by using indicators (1) duration of time, (2) material existence. The indicators in this study extract indicators and dimensions that adopt from the research of Dreyer and Gronhaug (2004); Koumanakos (2008); Keitany, et al., 2014; Bangka and Moronge (2017). Material management is a factor that is able to strengthen (moderator variable) the influence of competitive advantage on business performance in silver craft SMEs in Gianyar Regency.

\section{B. Competitive Advantage}

Competitive advantage is the added advantage of competitors by offering consumers greater value, either at lower prices or by providing products that provide better customer benefits and services. Competitive advantage theory can be obtained by applying differentiation, cost leadership, and focus (Porter, 1985). According to Porter (1990) that a country or organization is able to compete so as to encourage the creation of competitive advantage caused by four factors, including:

1) Condition factors (conditions factors), namely the position of a country in production factors such as the factors of skilled labor, infrastructure, and technology needed to compete in various industries.

2) The demand condition is the characteristic characteristic of a country's domestic demand for goods and or services in a particular industry.

3) The conditions of related and supporting industries, namely the existence or absence of supplier and other related industries that are superior nationally in certain countries.

4) Strategy, structure, and competition (strategy, structure, and revalry) are conditions that determine how companies are formed, organized, managed and the nature of domestic competition.

Porter (1985) argues that companies are able to produce products/services with lower costs compared to competitors is one way for competitive advantage. This is often achieved by large-scale organizations that develop efficiency by reasoning with their repeated experiences of the tasks involved or using their power to exploit lower costs. The same opinion was also expressed by Alfadda (2010) that competitive advantage for a company is largely determined by the characteristics within the company so that it views the company as a set of assets (resources) and capabilities. The company will be able to compete with resources that are able to run the basis of competitive advantage, namely: (a) resources that innovate, (b) social legitimacy (public trust in products), (c) flexibility in cultural values , (d) Learning organizations, (e) management capabilities, (f) global intelligence.

Several previous studies developed indicators to measure competitive advantage, among others, according to Ward et al. (1998) stated that competitive advantage can be measured into four dimensions, namely cost, quality, delivery, and flexibility. Competitive advantage can also be 
measured based on dimensions: cost efficiency, excellence in quality, timeliness (meeting timelines), work flexibility (work flexibility), innovative products (Kumarawadu, 2008).

Sarkindaji et al. (2014) state that competitive advantage is measured by dimensions consisting of: resource innovation, social legitimacy, organizational learning and management capabilities. Meutia and Ismail (2012) develop dimensions to measure competitive advantage based on product durability/long-term usage, difficult to replicate, ease. Rahman and Ramli (2014) state that competitive advantage can be measured in three dimensions, namely (1) cost leadership through efficiency, low cost (2) differentiation through product and service excellence, (3) focus through product line segments.

Kuncoro and Suriani (2017) develop dimensions to measure competitive advantage based on product uniqueness, product quality, competitive prices. In this study, competitive advantage is measured using dimensions developed by Ward et al. (1998), Kumarawadu (2008), Kuncoro and Suriani (2017), namely efficiency, product uniqueness, quality, competitive price, flexibility.

\section{Business Performance}

Younis, et al. (2010) stated that organizational business performance is the ability of an organization to achieve its goals and objectives, using economical, efficient and effective resources (3E). Performance is one of the objectives of business activities, this is aimed at the success of the organization in the long run.

Corina et al. (2011) states that there are several definitions to describe the concept of organizational performance, namely: (1) Performance is a set of financial and non-financial indicators that provide information on achieving goals and results. (2) Performance is dynamic, requires consideration and interpretation. (3) Performance is illustrated by the use of a causality model that explains how actions can affect future results. (4) Performance is understood differently depending on the people involved in evaluating organizational performance. (5) Explanation of the concept of performance requires knowledge of the characteristics of the elements for each field of responsibility. (6) For reporting the level of organizational performance requires the ability to quantify results. This is in line with the opinion of Fahmi (2011: 2) which explains that performance is a result obtained by organizations, both profit oriented organizations and non-profit oriented organizations.

According to Rahman and Ramli (2014) company performance is defined in terms of financial and nonfinancial performance. Financial performance consists of financial efficiency measures such as return on investment and returns, liquidity, and measures of profit such as profit on sales and net profit margin, profit, turnover or return on investment and non-financial covering autonomy, customer satisfaction, sales growth, growth employees, market share, job satisfaction, ability to balance work and family.

Measurement of organizational performance will be better if done more holistically, by combining aspects of measurement of financial and non-financial performance. By using non-financial measures, managers will be able to track progress on actionable steps that lead to the success of the company in the market with the company's values and preferences to produce decisions about the actions needed (Rahman and Ramli, 2014).

This research business performance variable is measured using four dimensions, namely: (1) finance, (2) customers, (3) operational (4) learning and growth. The financial dimension is reflected by indicators of liquidity, profitability, customer dimensions measured by indicators of the number of customers, customer satisfaction. Operational dimensions are proxied by product operational indicators, management operations, learning and growth dimensions reflected in indicators of employee learning, and employee satisfaction. The indicators in this study extract indicators and dimensions that adopted from Wang and Wang's research (2012); Yusof and Hasan (2012); Al-Hakim and Hassan (2013); Kipesha (2013); Sarkindaji et al. (2014); Tseng and Lee (2014); Alrubaiee et al. (2015); Valmohammadi and Ahmadi (2015); Oztekin et al. (2015), Ha et al. (2015); Kuhl et al. (2016); Byukusenge et al. (2016); Al-Sa'di et al. (2017); Kamboj and Rahman (2017), and Migdadi et al. (2017).

\section{Small and Medium Enterprises}

The development of small and medium enterprises, both by the government, regional government, business world, and society needs to be done and strengthened to grow and improve their ability and competitiveness. Small and medium enterprises are productive economic businesses that are independent, carried out by individuals or business entities that are not subsidiaries or not branches that are owned, controlled, or become a good part directly or indirectly from large businesses (Law of the Republic of Indonesia Number 20 of 2008). The criteria for small and medium enterprises from the BPS Province of Bali (2014) are determined according to the number of workers as the basis for determining the size of the company, presented in Table 1.

TABLE I: CRITERIA OF SMALL AND MEDIUM ENTERPRISES

\begin{tabular}{lll}
\hline \hline Description & $\begin{array}{l}\text { Small } \\
\text { Enterprises }\end{array}$ & $\begin{array}{l}\text { Medium } \\
\text { Enterprise }\end{array}$ \\
\hline $\begin{array}{l}\text { Net of asset (not including land } \\
\text { and buildings) }\end{array}$ & $\geq 50-500$ & $\geq 500-10,000$ \\
$\begin{array}{l}\text { Annual sales proceeds (million } \\
\text { Rupiahs) }\end{array}$ & $\geq 300-2,500$ & $\geq 2,500-50,000$ \\
Labor (people) & $5-19$ & $20-99$ \\
\hline \hline Source: Central Bureau of Statistics of Bali Province, 2014
\end{tabular}

\section{RESEARCH METHOdOLOGY}

Based on the literature review, a research conceptual framework can be drawn up as shown in Figure 1.

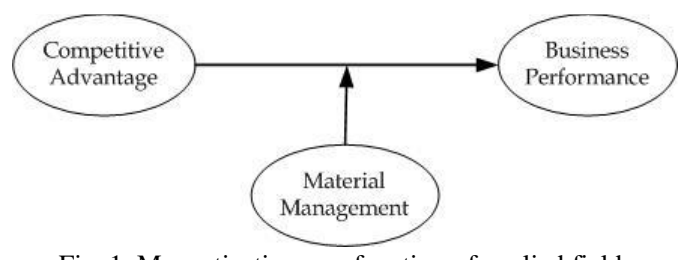

Fig. 1. Magnetization as a function of applied field.

The operational definitions of each variable can be explained as Table 2 . 
TABLE 2: VARIABLES, DIMENSIONS, AND INDICATOR OF RESEARCH

\begin{tabular}{|c|c|c|}
\hline Variable & Dimension & Indicator \\
\hline \multirow{10}{*}{$\begin{array}{l}\text { 1. Competitive } \\
\text { advantage } \\
\text { (X) }\end{array}$} & \multirow{2}{*}{$\begin{array}{ll}\text { a. } & \text { Efficiency } \\
& (\mathrm{X} 1)\end{array}$} & 1) Cost efficiency (X11) \\
\hline & & 2) Productivity (X12) \\
\hline & \multirow[t]{2}{*}{ b. Product } & 1) Product form (X21) \\
\hline & & 2) Product design (X22) \\
\hline & \multirow{2}{*}{$\begin{array}{l}\text { c. Product } \\
\text { quality (X3) }\end{array}$} & 1) Product durability (X31) \\
\hline & & 2) Product display (X32) \\
\hline & \multirow{2}{*}{$\begin{array}{l}\text { d. Competitive } \\
\text { price (X4) }\end{array}$} & 1) Product prices (X41) \\
\hline & & 2) Price comparison (X42) \\
\hline & \multirow{2}{*}{$\begin{array}{l}\text { e. Flexibility } \\
\text { (X5) }\end{array}$} & 1) Product variants (X51) \\
\hline & & 2) Product Adaptation (X52) \\
\hline \multirow{8}{*}{$\begin{array}{l}\text { 2. Business } \\
\text { performance } \\
(\mathrm{Y})\end{array}$} & \multirow[t]{2}{*}{ a. Finance (Y1) } & 1) Liquidity (Y11) \\
\hline & & 2) Rentability (Y12) \\
\hline & \multirow{2}{*}{$\begin{array}{l}\text { b. Costumer } \\
\text { (Y2) }\end{array}$} & 1) Number of customers (Y21) \\
\hline & & 2) Customer satisfaction (Y22) \\
\hline & \multirow{2}{*}{$\begin{array}{l}\text { c. Operational } \\
\text { (Y3) }\end{array}$} & 1) Product operations (Y31) \\
\hline & & $\begin{array}{l}\text { 2) Operational management } \\
\text { (Y32) }\end{array}$ \\
\hline & \multirow{2}{*}{$\begin{array}{l}\text { d. Learning and } \\
\text { growth (Y4) }\end{array}$} & 1) Learning for employees (Y41) \\
\hline & & 2) Employee satisfaction (Y42) \\
\hline \multirow{6}{*}{$\begin{array}{l}\text { 3. Material } \\
\text { management } \\
\text { (Z) }\end{array}$} & \multirow{2}{*}{$\begin{array}{l}\text { a. Procurement } \\
\text { of material } \\
\text { supplies (Z1) }\end{array}$} & 1) Quality of material (Z11) \\
\hline & & 2) Inventory management (Z12) \\
\hline & \multirow{2}{*}{$\begin{array}{l}\text { b. Material } \\
\text { control } \\
\text { system (Z2) }\end{array}$} & 1) Distribution of material (Z12) \\
\hline & & 2) Storage of material (YZ2) \\
\hline & \multirow{2}{*}{$\begin{array}{l}\text { c. Time lead } \\
(\mathrm{Z} 3)\end{array}$} & 1) Duration of time (Z31) \\
\hline & & 2) Existence of material (Z32) \\
\hline
\end{tabular}

As the research conceptual framework, the hypothesis of this study are:

1) Competitive advantage has a positive and significant effect on the business performance of silver craft SMEs.

2) Material management significantly strengthens the influence of competitive advantage on the business performance of silver craft SMEs.

The population in this study was silver crafts in Gianyar regency which amounted to 235 SMEs in silver crafts. Furthermore, the samples were calculated using the formula of Isaac and Michael, so that a sample of 146 SMEs was obtained. Sample selection was done by purposive sampling. The data in this study were collected through questionnaires and in-depth interviews. Furthermore, the data collected were analyzed using the SEM-PLS approach.

Competitive advantage has a positive and significant effect on the business performance of silver craft SMEs.

Material management significantly strengthens the influence of competitive advantage on the business performance of silver craft SMEs.

The population in this study were silver craft SME entrepreneurs in Gianyar Regency which amounted to 235 SMEs in silver crafts. Furthermore, the sample was calculated using the formula of Isaac and Michael, so that a sample of 146 SMEs in silver was obtained. Sample selection was done by purposive sampling. The data in this study were collected through questionnaires and in-depth interviews. Furthermore, the collected data was analyzed using the SEM-PLS approach.

\section{RESULTS}

\section{A. Results of Data Analysis with SEM-PLS Approach}

Data analysis using the SEM-PLS approach was carried out in two stages. The first stage is done by testing the outer model to test the validity and reliability of indicators for each construct. Next is the inner model test to find out the relationship between latent constructs.

Outer model testing is done by validity and reliability testing. The results of the validity test show that there are four invalid indicators, namely:

1) Indicators of material quality, on the dimensions of procurement and material inventory, material management variables;

2) Time duration indicator, in time lead dimension, material management variable.

3) Operational indicators of management, on the operational dimension, business performance variables.

4) Learning indicators for employees, on the dimensions of learning and growth, business performance variables.

The four indicators are then eliminated, and the outer model is tested again. The test results of the repeat outer model show that the entire outer model is valid and reliable, so that it can be continued by conducting an inner model test. Figure of research model with Smart-PLS application after eliminating invalid indicators as Figure 2.

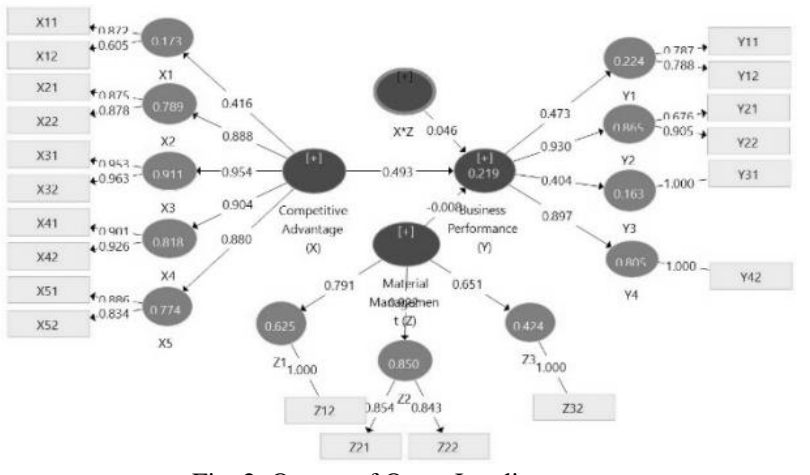

Fig. 2. Output of Outer Loading.

Inner model testing is done by evaluating the $\mathrm{R}$-square value. The R-square value of business performance is 0.219 , which means that $21.9 \%$ of the variation in value of the business performance of silver craft SMEs can be explained by the construction of the model in this study. While the remaining $78.1 \%$ is explained by other factors.

The next step is to analyze the results of the influence between research variables. The output of the influence between research variables is as shown in Table 3.

TABLE 3: PATH COEFFICIENT

\begin{tabular}{cccccc}
\hline \hline & $\begin{array}{c}\text { Original } \\
\text { Sample }\end{array}$ & $\begin{array}{c}\text { Sample } \\
\text { Mean }\end{array}$ & $\begin{array}{c}\text { Standard } \\
\text { Deviation }\end{array}$ & T-Statistics & P Values \\
\hline $\mathrm{X} \rightarrow \mathrm{Y}$ & 0.493 & 0.550 & 0.129 & 3.829 & 0.000 \\
$\mathrm{Z} \rightarrow \mathrm{Y}$ & -0.008 & 0.004 & 0.068 & 0.125 & 0.901 \\
$\mathrm{X} * \mathrm{Z} \rightarrow \mathrm{Y}$ & 0.046 & 0.016 & 0.170 & 0.271 & 0.787 \\
\hline \hline
\end{tabular}

Note: $\mathrm{X}=$ competitive advantage; $\mathrm{Y}=$ business performance; $\mathrm{Z}=$ material management

\section{B. Results of Hypothesis Testing}

The research hypothesis testing can be done by paying attention to $\mathrm{t}$-value and p-value on the path coefficients. Based on Table 2., it is known that:

1) On the influence of competitive advantage on business 
performance, t-value is 3,829 , which means greater than t-table (1.96) and p-value 0,000, which means it is smaller than the significance level $(0.05)$. The path coefficient value is also positive, so it can be said that competitive advantage has a positive and significant effect on business performance, and means that the first research hypothesis is accepted.

2) On the influence of material management on business performance, the t-value is 0.125 , which means it is smaller than t-table (1.96) and p-value 0.902, which means it is greater than the significance level (0.05), so material management is directly no significant effect on business performance. Furthermore, to test the role of material management as a moderator, it is known that the $\mathrm{t}$-value is 0.271 , which means that it is smaller than $\mathrm{t}$ table (1.96) and p-value 0.787 which means greater than the significance level (0.05), so material management is not a significant moderator on the influence of competitive advantage on business performance. This means that the second research hypothesis was rejected.

\section{DISCUSSION}

\section{A. The Effect of Competitive Advantage on Business} Performance of Silver Craft SMEs in Gianyar Regency

Based on the results of the hypothesis test, it can be seen that competitive advantage has a significant positive effect on the business performance of silver craft SMEs in Gianyar Regency. This indicates that the competitive advantage of the silver craft SMEs is increasing, it will be able to improve the company's business performance. The ability of silver craft SME businesses to produce products that have competitiveness, quality, uniqueness, price, and product flexibility will certainly be able to compete in the market. Products that are unique in both design and shape will certainly be in demand by customers The ability of silver craft SMEs to produce products at affordable prices, able to compete with competitors, durable product quality, and in accordance with customer orders/desires, will certainly give satisfaction to customer. This condition will increase the value of sales and market share.

\section{B. The Role of Material Management as Moderator on \\ The Effect of Competitive Advantage on Business Performance of Silver Craft SMEs in Gianyar Regency}

The results of data analysis show that material management turned out to moderate with no significant influence of competitive advantage on business performance. Given that the direct influence of material management on business performance is also insignificant, moderation is a potential moderation.

As we know that the main raw material for silver is silver, and other materials are supporting materials. The role of material management in this study is influential but not significant as moderating the influence of competitive advantage on business performance. This is caused by two things (1) the characteristics of material products, and (2) the behavior of silver craft SMEs in managing materials.

In terms of product or material characteristics, it can be explained that the characteristics of silver raw materials that do not have expiration, so the function of material storage is not very functional in silver craft SMEs. Most of the silver craft SMEs have never recorded in detail about the period of silver purchases as well as the use of raw materials to produce products. They use material calculators to produce products based on their perceptions based on the experience they have had while becoming craftsmen or silver craftsmen. The raw material entry and exit system is not really needed in silver craft SMEs. The material quality of silver as raw material is relatively the same and already has certain standards that have become an agreement, which distinguishes only supporting raw materials which become a mixture of silver material. Therefore the selection of suppliers about the quality of silver is stated to be not very important in material procurement. The price of silver material is relatively stable. This is due to the fact that in one of the silver SMEs centers, it already has a silver craftsman cooperative institution that has been able to fulfill the needs of business people for silver raw materials. The silver craftsmen cooperative has collaborated with the Antam company as a silver material producer to supply silver raw materials to SME silver entrepreneurs as needed. These conditions certainly make it easier for businesses to obtain silver material or other supporting raw materials and as needed.

In terms of behavior, businessmen of silver crafts SMEs can be seen that almost all of the businessmen of silver craft SMEs only receive production costs. This means that all designs and/or raw materials/silver material in producing products are borne by customers who order silver craft products. Silver craft businessmen do not need to purchase material carefully and selectively, or determine the amount of material ordered according to the requirements of silver raw materials for the production process. Most material inventory management is determined by the customer. If even the silver craft SME businessmen order silver material, they order material according to the needs in producing ordered products. Silver business people do not need to order material stocks, or do material stock storage planning.

The characteristics of SMEs in silver crafts are mostly in the form of small businesses (SEs) and medium enterprises (MEs), so that company management is managed simply. If management is made with the stockist system (inventory system) certainly requires high costs, one of which must recruit employees who specifically handle or understand material supplies. On the other hand, orders from customers are relatively uncertain in terms of time and quantity of orders, which will certainly have an impact on company performance. Businessmen in silver craft SMEs in Gianyar are more than 70 percent in the form of small businesses, automatically they have limited capital. Most of the silver craft SMEs do not stock silver material, if they stock large quantities of material they will experience idle raw materials, and will certainly be overwhelmed in optimizing business performance.

\section{CONCLUSIONS}

Based on the results of data analysis it can be concluded that competitive advantage has a positive and significant effect on business performance in silver craft SMEs in Gianyar Regency. This means that to improve business performance, silver craft SMEs must be able to create products (in this case silverware) that have advantages in 
terms of efficiency, product uniqueness, product quality, competitive prices, and flexibility.

However, material management turns out that directly and as a moderator has no significant effect on business performance in silver craft SMEs in Gianyar Regency. This is because the character of the raw material and the way to obtain raw materials (in this case in the form of silver), and the character of the business does not yet require a complex material management system.

As a recommendation, it is recommended that silver craftsmen carry out material management in a simple but careful The limitation in this study is the assessment of business performance through perceptual valuation, not valuing the ratio or financial condition of the company. This study also has not examined the marketing of silver, even though marketing factors greatly determine business performance. Therefore, future research needs to link business performance factors with marketing, innovation, and even entrepreneurial orientation.

\section{REFERENCES}

[1] A. F. Al-Sa'di, A. B. Abdallah, and S. E. Dahiyat, "The Mediating Role of Product and Process Innovations on The Relationship Between Knowledge Management and Operational Performance in Manufacturing Companies in Jordan”, Business Process Management Journal, vol. 23, iss 2, 2017.

[2] A. Oztekin, D. Delen, H. Zaim, A. Turkyilmaz, and S. Zaim, "The Influence of Knowledge Management on Financial and Non-Financial Performance," Journal of Information \& Knowledge Management, Vol. 14, No. 2, 2015.

[3] B. Alfadda, "Institutional Renewal And Adaptation (IRA): Creating And Managing Sustainable Competitive Advantage (SCA)," Thesis, University of Maryland University College, USA, 2010.

[4] B. Dreyer, and K. Gronhaug, "Uncertainty, Flexibility, and Sustained Competitive Advantage," Journal of Business Research, vol. 57, pp 484-494, 2004.

[5] B. D. Sarkindaji, N. A. Bin Hashim, and A. O. Abdullateef, 2014. Knowledge Management and Organizational Performance of Mobile Service Firms in Nigeria: A Proposed Framework. Information and Knowledge Management, Vol.4, No.11, 2014.

[6] C. Bagaka and M. Moronge, "Role of Material Management on Performance of Sugar Manufacturing Industries in Kenya Case of Mumias Sugar Company Limited", The Strategic Journal of Business \& Change Management, vol. 4, iss. 1 (12), pp 227 - 245, 2017.

[7] C. Valmohammadi and M. Ahmadi, "The Impact of Knowledge Management Practices on Organizational Performance A Balanced Scorecard Approach," Journal of Enterprise Information Management, vol. 28, no. 1, 2015 pp. 131-159, 2015.

[8] Central Bureau of Statistics of Bali Province, Bali in Figure 2014, Denpasar: Central Bureau of Statistics of Bali Province, 2014.

[9] D. P. Koumanakos, "The Effect of Inventory Management on Firm Performance," International Journal of Productivity and Performance Management, vol. 57, iss 5, pp. 355-369, 2008,

[10] E. Byukusenge, J., Munene, and L. Orobia, "Knowledge Management and Business Performance: Mediating Effect of Innovation," Journal of Business and Management Sciences, vol. 4, no. 4, 82-92, 2016.

[11] E. F. Kipesha, "Performance of Microfinance Institutions in Tanzania: Integrating Financial and Non financial Metric," European Journal of Business and Management, vol. 5, no. 4, 2013.

[12] G. Corina, I. Liviu, and S. Roxana, "Determinants of Organizational Performance: the Case of Romania," Journal Management \& Marketing Challenges for the Knowledge Society, vol. 6, no 2, pp 285-300, 2011

[13] G. O. Ondiek, O. Odera, and M. Muliro, "Assessment of Materials Management in Kenyan Manufacturing Firms," Journal of Business Studies Quarterly, vol. 3, no. 3, pp. 40-49, 2012.

[14] J. A. I. Younis, Y. Nor'Aini, and N. Davoud, "A Review Paper on Organizational Culture and Organizational Performance,"
International Journal of Business and Social Science, vol. 1, no. 3 , 2010.

[15] L. A. Y. Al-Hakim and S. Hassan, "Knowledge Management Strategies, Innovation, and Organisational Performance An Empirical Study of The Iraqi MTS," Journal of Advances in Management Research, vol. 10, no. 1, pp. 58-71, 2013.

[16] L. Alrubaiee, H. M. Alzubi, R. Hanandeh, and R. A. All, "Investigating the Relationship Between Knowledge Management Processes and Organizational Performance The Mediating Effect of Organizational Innovation", International Review of Management and Business Research, vol. 4 issue.4 pp 989-1009, 2015.

[17] M. E. Porter, Competitive Advantage: Creating and Sustaining Superior Performance, New York: New York Press, 1985

[18] , "The Competitive Advantage of Nations," Harvard Business Review, March-April 1990 Issue, 1990.

[19] M. Migdadi, M. K. A. Zaid, M. Yousif, R. Almestarihi, and K. AlHyari, "An Empirical Examination of Knowledge Management Processes and Market Orientation, Innovation Capability, and Organizational Performance: Insights from Jordan," Journal of Information \& Knowledge Management," vol. 16, no. 1, 2017.

[20] M. N. Yusof and A. H. Abu-Bakar, "Knowledge Management and Growth Performance in Construction Companies: A Framework," Procedia Social and Behavioral Sciences, vol. 62, pp. 128-134, 2012.

[21] M. R. Kuhl, J. C. da Cunha, M. B. Macaneiro, and S. K. Cunha, "Relationship Between Innovation and Sustainable Performance," International Journal of Innovation Management, vol. 20, no. 3, 2016.

[22] Meutia and T. Ismail, "The Development of Entrepreneurial Social Competence And Business Network to Improve Competitive Advantage And Business Performance of Small Medium Sized Enterprises: A Case Study of Batik Industry In Indonesia," Procedia Social and Behavioral Sciences, vol. 65, pp 46-51, 2012.

[23] N. A. A. Rahman, and A. Ramli, "Entrepreneurship Management, Competitive Advantage and Firm Performances in the Craft Industry: Concepts and Framework," Procedia - Social and Behavioral Sciences, 145, 129-137, 2014.

[24] P. J. Keitany, D. M. Wanyoike, and S. Richu, “Assessment Of The Role of Materials Management on Organizational Performance A Case of New Kenya Cooperative Creameries Limited Sciences," European Journal of Material Sciences, vol. 1, no. 1, pp. 1-10, 2014.

[25] P. Kumarawadu, "Achieving Competitive Advantage through Knowledge Management Initiatives in Small and Medium Software Industry," Journal of Information \& Knowledge Management, vol. 7 , no. 4 pp. 255-265, 2008.

[26] P. T. Ward, J. K. McCreery, L. P. Ritzman, and D. Sharma, "Competitive Priorities in Operations Management," Decision Sciences, vol. 29 (4), pp. 1035-1046, 1998.

[27] S. Kamboj, and Z. Rahman, "Market Orientation, Marketing Capabilities and Sustainable Innovation: The Mediating Role of Sustainable Consumption and Competitive Advantage," Management Research Review, vol. 40, issue: 6, 2015.

[28] S. M. Tseng and P. S. Lee, "The Effect of Knowledge Management Capability and Dynamic Capability on Organizational Performance," Journal of Enterprise Information Management, vol. 27, no. 2, pp. 158-179, 2014

[29] S. T. Ha, M. C. Lo, and Y. C. Wang, "Relationship between Knowledge Management and Organizational Performance: A Test on SMEs in Malaysia," Procedia - Social and Behavioral Sciences, 224, pp. $184-189,2015$.

[30] V. W. Naliaka dan G. S. Namusonge, "Role of Inventory Management on Competitive Advantage among Manufacturing Firms in Kenya: A Case Study of Unga Group Limited," International Journal of Academic Research in Business and Social Sciences, vol. 5, no. 5, 2015.

[31] W. Kuncoro and W. O. Suriani. (2017). Achieving Sustainable Competitive Advantage Through Product Innovation and Market Driving. Asia Pacific Management Review. [Online]. Available: http://dx.doi.org/10.1016/j.apmrv.2017.07.006.

[32] Y. Kathawala and H. H. Nauo, "Integrated Materials Management: A Conceptual Approach," IJDP \& MM, vol. 19, no. 8, 2007.

[33] Z. Wang, and N. Wang, "Knowledge Sharing, Innovation and Firm Performance," Expert Systems with Applications, vol. 39, no. 1, pp. 8899-8908, 2012. 